\title{
IS THE BASAL ICE OF A TEMPERATE GLACIER AT THE PRESSURE MELTING POINT?
}

\author{
By G. DE Q. RobIN \\ (Scott Polar Research Institute, Cambridge, England CB2 I ER)
}

\begin{abstract}
Certain aspects of the flow of glaciers suggest that molecular adhesion contributes to basal friction of glaciers sliding at speeds below those of surging glaciers. Laboratory experiments indicate that this will only occur if some part of the ice-rock contact is "cold", that is below the pressure melting point (p.m.p.), a few tenths of a degree being sufficient. Field evidence is scanty, but suggests that such cold patches may exist at the base of a temperate glacier.

Discussion of pressure-melting within the basal ice mass, as distinct from processes at the ice-rock contact, indicate that excess water is formed in zones of high-pressure ice up-stream of obstacles. If this water is squeezed out of the ice by the pressure, we have a simple heat pump that will tend to cool the basal ice. The ice will warm again as the result of thermal conduction and internal friction, but before reaching the p.m.p. it can produce "cold" patches of the ice-rock contact, roughly estimated to be from o. I to $\mathrm{I} .0 \mathrm{~m}$ in extent.

Another factor that could cause intermittent cold patches at the ice-rock interface arises from changes of basal water pressures with time beneath a glacier. If a major part of the weight of a glacier is supported by a thin water film at a relatively low pressure and by a small proportion of water film in which pressures are high, then over a large area the water pressures must balance the weight of ice. If however the pressure in the low-pressure film rises, the smaller high-pressure areas of stress concentration will suffer a proportionately greater decrease of pressure to maintain the total balance between pressure and weight. If changes take place rapidly, in a matter of hours, then in areas of stress concentration of the order of a metre or more across, the water film will freeze to the bed as stresses are relieved. This could cause stick-slip motion in a temperate glacier.
\end{abstract}

Pressure-temperature effects at the ice-rock interface can help to explain certain features of glacial erosion, such as intense grinding on the top surface of a roche moutonnée and plucking on the down-stream side.

RÉsumé. La glace d'un glacier tempéré est-elle au point de fusion correspondant à la pression le long du lit rocheux? Certains aspects de l'écoulement des glaciers suggèrent que l'adhésion moléculaire contribue au frotement sur le socle de glaciers glissants à des vitesses inférieures à celles des glaciers en crue rapide. Des expériences de laboratoire indiquent que ceci n'arrivera que si une partie du contact glace-rocher est "froid", c'est-à-dire en-dessous du point de fusion correspondant à la pression (p.m.p.), quelques dixièmes de degré étant suffisants. Les preuves matérielles sont peu nombreuses sur le terrain, mais elles suggèrent que de telles traînées froides peuvent exister à la base d'un glacier tempéré.

Une discussion sur le point de fusion selon la pression à l'intérieur de la masse de la glace de base, qui est à distinguer des phénomènes au contact glace-rocher, indique que de l'eau en excès se forme dans les zones de glace à haute pression, à l'amont des obstacles. Si cette eau est évacuée hors de la glace par la pression, nous avons une simple pompe à chaleur qui tend à refroidir la glace du fond. La glace va se réchauffer à nouveau par conduction thermique et friction interne, mais avant d'atteindre le p.m.p., elle peut produire des traînées froides au contact glace-rocher, dont on peu estimer grossièrement la largeur entre $0, \mathrm{I}$ et $\mathrm{r}, \mathrm{O} \mathrm{m}$.

Un autre facteur qui pourrait provoquer par intermittence des traînées froides à l'interface glace-rocher, découle des changements de pression avec le temps dans l'eau sous un glacier. Si une majeure partie du poids du glacier est supportée par un mince film d'eau, à une pression relativement basse, et par une petite proportion d'un film d'eau à haute pression, alors sur une grande surface la pression de l'eau doit équilibrer le poids de la glace. Mais si la pression dans le film liquide à faible pression vient à augmenter, les surfaces plus réduites à haute pression par concentration des efforts, devront subir une baisse de pression proportionnellement plus grande pour maintenir l'équilibre global entre la pression totale et le poids du glacier. Si ces changements se produisent rapidement, en un temps qui s'estime en quelques heures, alors, dans les secteurs de concentration des contraintes, d'une largeur de l'ordre du mètre ou plus, le film liquide va regeler en adhérent au roc lorsque les efforts subis se relâchent. Ce mécanisme peut entraîner un mouvement de glissement avec glace adhérente, dans un glacier tempéré.

Les effets de la pression et de la température à l'interface glace-rocher, peuvent tenter d'expliquer certains caractères de l'érosion glaciaire, tels que le broyage intense sur la surface d'une roche moutonnée et l'arrachage de blocs sur le côté aval.

Zusammenfassung. Befindet sich das Eis am Grunde eines temperierten Gletschers auf dem Druckschmelzpunkt? Gewisse Anzeichen legen die Vermutung nahe, dass beim Gletscherfliessen die molekulare Adhäsion einen Beitrag zur Reibung am Untergrund von solchen Gletschern liefert, die mit einer geringeren Geschwindigkeit gleiten als ausbrechende Gletscher. Laborversuche zeigen, dass dies nur dann der Fall ist, wenn ein Teil der Kontaktzone zwischen Eis und Fels "kalt" ist, d.h. unterhalb des Druckschmelzpunktes (DSP), wobei wenige Zehntelgrade bereits genügen. Beobachtingen darüber sind kärglich, doch stützen sie die Annahme, es könnten kalte Stellen am Untergrund eines temperierten Gletschers auftreten.

Die Untersuchung der Druckschmelze innerhalb der Eismasse am Untergrund, die wohl zu unterscheiden ist von den Vorgängen in der Berührzone von Eis und Fels, zeigt, dass überschüssiges Wasser in Zonen 
hochkompressiven Eises oberhalb von Hindernissen auftritt. Wenn dieses Wasser durch Druck aus dem Eis gepresst, wird, haben wir eine einfache Wärmepumpe, die eine Kühlung des Eises am Untergrund bewirkt. Das Eis wird sich infolge der Wärmeleitung und inneren Reibung wieder erwärmen bevor es jedoch den DSP wieder erreicht, können "kalte" Stellen im Kontaktbereich von Eis und Fels entstehen, deren Ausmass sich grob auf $\mathrm{o}, \mathrm{I} \mathrm{m}$ bis $\mathrm{I}, \mathrm{O} \mathrm{m}$ schätzen lässt.

Ein weiterer Grund für das Auftreten kalter Stellen an der Grenzfläche zwischen Eis und Fels liegt in der zeitlichen Änderung des Wasserdruckes unter einem Gletscher. Wenn ein Grossteil des Gletschergewichtes von einem dünnen Wasserfilm unter relativ geringem Druck und einem nur kleinen Anteil von Wasserfilm unter hohem Druck getragen wird, dann muss der Wasserdruck über einen weiten Bereich dem Eisgewicht die Waage halten. Wenn jedoch der Druck in dem Film mit niedrigem Druck ansteigt, dann tritt in den kleineren Hochdruckzonen mit Spannungskonzentration ein verhältnissmässig grösserer Druckabfall zur Aufrechterhaltung des gesamten Gleichgewichtes zwischen Druck und Gewicht ein. Finden solche Schwankungen schnell, innerhalb von Stunden, statt, dann wird der Wasserfilm in Gebieten mit Spannungskonzentration von der Grössenordnung eines Meters oder mehr an den Untergrund anfrieren, wenn die Spannung nachlässt. Dies könnte zu ruckartigen Bewegungen in einem temperierten Gletscher führen.

Wirkungen von Druck und Temperatur an der Grenzfläche zwischen Eis und Fels können zur Deutung gewisser Erscheinungen der glazialen Erosion herangezogen werden, etwa der kräftigen Schliffe auf den Kuppen von Felsbuckeln (roche moutonnée) und der Ausbrüche an den stromabgewandten Flanken.

\section{INTRODUGTION}

A temperate glacier was defined by Ahlmann (1935) as one in which ice below the level affected by seasonal fluctuations was at the pressure-melting point (p.m.p.). However, extensive use of bore holes for the study of glaciers has shown that water in some bore holes slowly freezes even though the glaciers are believed to be temperate. Certain aspects of this problem have been studied and discussed by Harrison (1972).

The present paper raises a similar question in relation to the basal layers of ice in a temperate glacier. The usual assumption is that the basal ice in such glaciers is separated from bedrock by a continuous thin film of water, and this assumption plays a major role in theories of the sliding of glaciers. It implies that pressure at the water film is normal to the ice-rock interface and that no shearing takes place as a result of adhesion between ice and rock. However, consideration of field data by Budd (personal communication, to be published) suggests that such adhesion is present when glaciers are sliding at relatively low speeds, but that this adhesion ceases at the higher velocities of sliding associated with surging glaciers. In the context of the present symposium I propose to discuss temperature factors as a possible cause of molecular adhesion between ice and bedrock.

Weertman's well known theory of glacier sliding (1957; 1964) and papers on sliding by Kamb and LaChapelle (r964), Lliboutry (1964-65; r 968$)$, Nye (I969), and Kamb (r97o) all deal with pressure melting and regelation processes but do not introduce the concept of molecular adhesion.

The role of adhesion during the sliding of ice over various solids has been studied in the laboratory in Cambridge, England, over some years and reported by Barnes and others (1971), following the earlier work on adhesion of Raraty and Tabor (1958). Other processes of importance to our understanding of the sliding of glaciers, including the rapid increase in deformation rate when pressures rise above the pressure melting point, were described by Barnes and Tabor (1966, I 968$)$. However, no reference to these papers is made in any of the theoretical papers on sliding mentioned so far. In fairness it must be pointed out that on occasion Lliboutry has drawn attention to the lack of adequate theoretical treatment of variations in the flow properties of ice in the presence of appreciable quantities of melt water. Nye (1973) has also discussed some paradoxes met in regelation theory, especially in relation to boundary conditions and heat flow.

It is hoped that discussion of temperature effects in this paper will cause theoreticians to pause in developing more complex mathematical models of sliding in order to study whether or not the assumptions on which their theories are based involve an adequate description of conditions and processes in the basal layers of glaciers. This paper deals specifically with the possibility that adhesion at the ice-rock interface could be significant, as well as considering 
some associated problems of heat flow. One referee has drawn attention to the role of impurities as "They might be a dominant cause of cold patches where adhesion could occur". This suggestion, as well as other ideas, warrants further investigation. The changing physical properties of a parcel of ice as it moves through variations in the pressure and temperature field around a bedrock irregularity also require further consideration, which might be helped by the discussion of temperature factors in this paper. Apart from these general points which are relevant to all the theoretical papers quoted above, attention will only be drawn to aspects of these earlier papers which differ from-or are relevant to-the discussion in this paper.

Laboratory studies by Barnes and others (I97I) on the friction of polycrystalline ice sliding on a smooth granite surface show how the friction varies with temperature and the velocity of sliding (Fig. I). The flat contact region between the ice and granite was about 5 to ro $\mathrm{mm}$ in diameter and the loads were from 310 to $1 \mathrm{I} 8 \mathrm{o} \mathrm{N}$. These are similar to mean loading on the base of a glacier from 400 to $5000 \mathrm{~m}$ thick, or to the higher loading on locally high areas of the glacier bed in glaciers of the order of one-tenth those thicknesses, if the stresses are concentrated by a factor of about ten on such areas. In the experiments of Barnes and others it was shown that their "ploughing" term was small. In a glacier, one cannot eliminate the "ploughing" or deformation term due to the irregular shape of the bedrock beneath a glacier. Figure I provides information only on the "non-ploughing" component of friction, which these experiments show is primarily due to adhesion between ice and rock. However, Raraty and Tabor (1958) showed that the adhesion of ice to clean surfaces increased linearly with lowering of temperature beneath the melting point. Therefore, if we are to apply the results of Barnes and others to temperate glaciers, we must show that a small percentage of the area of the ice-rock contact beneath such glaciers is below the pressure melting point, preferably by a few tenths of a degree Celsius.

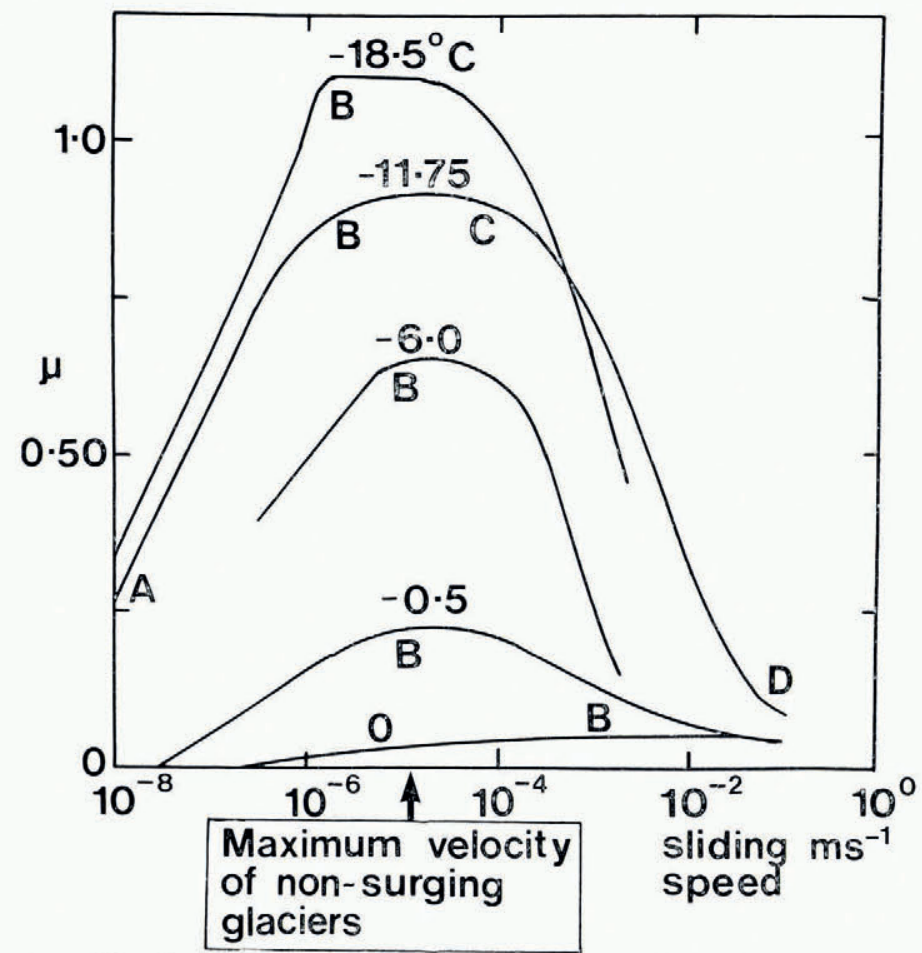

Fig. I. Friction of polycrystalline ice sliding on granite at various temperatures from Barnes and others (I97I) with addition of arrow indicating approximate upper limit to speed of glaciers before drop in basal friction leads to surge-type flow. 


\section{Field EVIDENCE}

Owing to considerable technical difficulty (due to the environment) there appears to be a complete lack of direct measurements of ice temperatures close to the ice-rock contact beneath a temperate glacier. Even if direct measurements are made, they will still be difficult to interpret unless we also know the pressure-melting temperature at the same point, possibly by measurement of the hydrostatic pressure. Perhaps discussions following this paper will stimulate someone to make such measurements. In the meantime we must look at indirect evidence.

Some measurements of air temperatures in natural tunnels beneath glaciers are available. Theakstone ( 1967 ) reported that air temperatures in a tunnel beneath $50 \mathrm{~m}$ of ice near the margin of Østerdalsisen in Norway remained almost constant at $-1.0^{\circ} \mathrm{C}$ except during periods of rain which produced warming due to an increased amount of water entering the tunnel from outside. Nevertheless, on occasion a film of water was seen to trickle down from the ice-rock contact above the rock step that formed the tunnel. Vivian and Bocquet (1973, p. 44I) reported air temperatures which vary a little around $+0.5^{\circ} \mathrm{C}$ in the tunnels they studied beneath the Glacier d'Argentière while the rock is coated discontinuously with ice. They reported (p. 443) that the vault carried "ice efflorescences following on the phenomena of decompression on the ice-air interface" (Kamb and LaChapelle (1964) also described this). Vivian and Bocquet's figure 4 also shows the slow freezing of water pockets formed down-stream of rocks carried in the ice as they moved across the tunnel. It seems clear that the ice roof of natural subglacial caverns is often below melting point at atmospheric pressure, a depression of about $\mathrm{I}^{\circ} \mathrm{C}$ being suggested. Clearly these temperatures result from the lower melting point of ice under stress up-stream of the tunnel.

A valuable and frequently quoted set of observations are those of Carol (1947) who was able to penetrate natural cavities around a roche moutonnée under some $50 \mathrm{~m}$ of ice of the Ober Grindelwaldgletscher. Referring to ice up-stream of the obstacle, at heights estimated from his figure 8 to be up to $70 \mathrm{~cm}$ above the bedrock, he wrote: "It was not surprising to find that water exuded from countless capillaries and that pieces of ice hacked out had almost the consistency of cheese", whereas he referred to ice on the lee side of the obstruction as rigid.

Apart from Carol's observations, one can only deduce the thickness of the layer in which appreciable melting takes place within the ice if one assumes that this is the same as the thickness of the basal layer of clear ice or "sole" of a glacier, as suggested by Barnes and Robin (1966). The thickness of this layer was $30 \mathrm{~cm}$ beneath a cirque glacier (Vesl-Skautbreen) in Norway, $50 \mathrm{~cm}$ beneath Blue Glacier studied by Kamb and LaChapelle, while Vivian and Bocquet suggest, on the basis of crystallographic evidence, that the basal layer is over $1.5 \mathrm{~m}$ thick at the Glacier d'Argentière and more than $2 \mathrm{~m}$ thick under the Mer de Glace and do not rule out a maximum thickness approaching $10 \mathrm{~m}$.

Evidence on the presence of a film of water comes from direct observations in tunnels, and from changes of water level in bore holes when bedrock has been reached. Possibly observations by Kamb and LaChapelle (1964) beneath Blue Glacier are most relevant to this paper since, although made beneath only $26 \mathrm{~m}$ of ice, they illustrate the effect of changing pressures on a water film. They reported that, when overburden pressure is removed from ice in contact with bedrock by excavating the ice above and around it, the basal ice freezes fast to the rock. However, when excavated quickly without initial release of overburden pressure, the ice came free from the sole and was not frozen to it. Furthermore, excavated blocks of basal ice were freed from the sole by irradiating momentarily with a photoflood lamp. Simple calculations indicate that a water film ro $\mu \mathrm{m}$ in thickness requires absorption of around $0.08 \mathrm{cal} \mathrm{cm}^{-2}\left(3 \times \mathrm{IO}^{-5} \mathrm{~J} \mathrm{~m}^{-2}\right)$ of latent heat to freeze the water. This amount of heat could be supplied by conduction in about $I_{5} \mathrm{~s}$ if the p.m.p. of the ice is suddenly raised by $0 . \mathrm{I}^{\circ} \mathrm{C}$ by removal of pressure (see Fig. 4 later). It therefore appears that time variations of basal 
pressure can cause freezing of ice to rock if the water film is only a few micrometres thick. In this paper, we consider the effects of spatial, as well as time, variations of pressure beneath glaciers.

Although there is no direct observation of the absence of a water film beneath a temperate glacier, and it is normally present, existing observations do not preclude the possibility that it may be absent over a fraction of the basal area of a glacier. A line of evidence which suggests indirectly that basal freezing may occur is the intermittent motion of temperate glaciers. Both Theakstone (1967) and Vivian and Bocquet (r973) have shown that this stick-slip type of motion occurs in basal ice in the vicinity of the glacier tunnels they studied. Figure 7 of the latter paper indicates a complete stoppage of sliding for at least one hour on three occasions in six days near the separation of ice from rock. Both parties found less variation of motion well clear of the ice-rock contacts, which suggests that the area over which the stoppage occurred is of smaller dimensions than the tunnel arch-say, of the order of a metre or even of decimetres. Such stick-slip behaviour can be understood if the ice-rock interface beneath a temperate glacier is below p.m.p. over an appreciable area, but is difficult to explain otherwise. In their laboratory experiments at - I I. $75^{\circ} \mathrm{C}$, Barnes and others (I 97 I) noted stick-slip as the dominant type of sliding between points B and c (Fig. I).

\section{THEORETICAL CONSIDERATIONS}

The usual approach to studies of the sliding of glaciers is to consider that normal pressures at the ice-rock interface are the same as the hydrostatic pressure in the water film, hence the temperature $\theta$ can be found from the Clausius-Clapeyron relationship $\theta=p \Delta v / \Delta s \approx$ $\left(-7.4 \times \mathrm{IO}^{-2} \mathrm{deg} \mathrm{m}^{2} \mathrm{MN}^{-1} p\right)$ where $\Delta v$ and $\Delta s$ are the changes of volume and entropy on melting and $p$ is the hydrostatic pressure.

The temperature field thus produced in a particular case, such as a sinusoidal shape of bedrock, or by cubical obstacles, is then used to calculate the thermal conduction through ice and rock, and hence determine the permissible amount of pressure melting and regelation in the particular model, and thus the velocity of sliding due to this process. In addition, effects of deformation must be taken into account, the latter being important around the larger obstacles or longer wavelengths.

Although much can be learned from these calculations, they neglect various factors. Some of these were reviewed by Lliboutry ( 1968, p. 38$)$ and may be of importance in relation to cold patches of bedrock. The first factor is the transport of heat by movement of ice. Lliboutry, by means of an approximate equation, and Kamb (I970) by introduction of approximations to an exact solution have both shown that the advection of heat by movement of ice is almost negligible at low velocities of sliding (up to $20 \mathrm{~m} \mathrm{a}^{-1}$ ). However, the approximations in both cases break down when velocities of sliding are an order of magnitude greater, as is the case for Glacier d'Argentière with an average basal velocity of $257 \mathrm{~m} \mathrm{a}^{-1}$.

We show the effect of linear motion on temperature distribution in Figure 2 from more precise calculations based on equations $4.9(5,6)$ of Carslaw and Jaeger ( I 959). Over Io cm distance, the temperature distribution is hardly altered by ice movement of $\mathrm{IO}^{-6} \mathrm{~m} \mathrm{~s}^{-1}$ $\left(33 \mathrm{~m} \mathrm{a}^{-1}\right)$, but at $\mathrm{IO}^{-5} \mathrm{~m} \mathrm{~s}^{-1}\left(330 \mathrm{~m} \mathrm{a}^{-1}\right)$ a small effect is noticed. Over $100 \mathrm{~cm}$, however, movement of $10^{-6} \mathrm{~m} \mathrm{~s}^{-1}$ has a small effect on temperature distribution, while the temperature field is clearly dominated by movement of $\mathrm{IO}^{-5} \mathrm{~m} \mathrm{~s}^{-1}$, to the extent that thermal conduction has little effect on ice temperatures more than $50 \mathrm{~cm}$ up-stream of the warmer surface.

It is clear that at higher velocities of motion around larger irregularities, advection of heat should not be neglected, since field evidence suggests that the regelation process remains important over lengths up to $50 \mathrm{~cm}$.

Observations and analyses of data in Kamb (1970) are of particular interest. For his example 3 in table 4 , where the ice is sliding at $5.8 \mathrm{~m} \mathrm{a}^{-1}$, he predicts a regelation layer thickness of between $\mathrm{I} .2$ and $9.5 \mathrm{~mm}$, which compares with an observed maximum $29 \mathrm{~mm}$ 

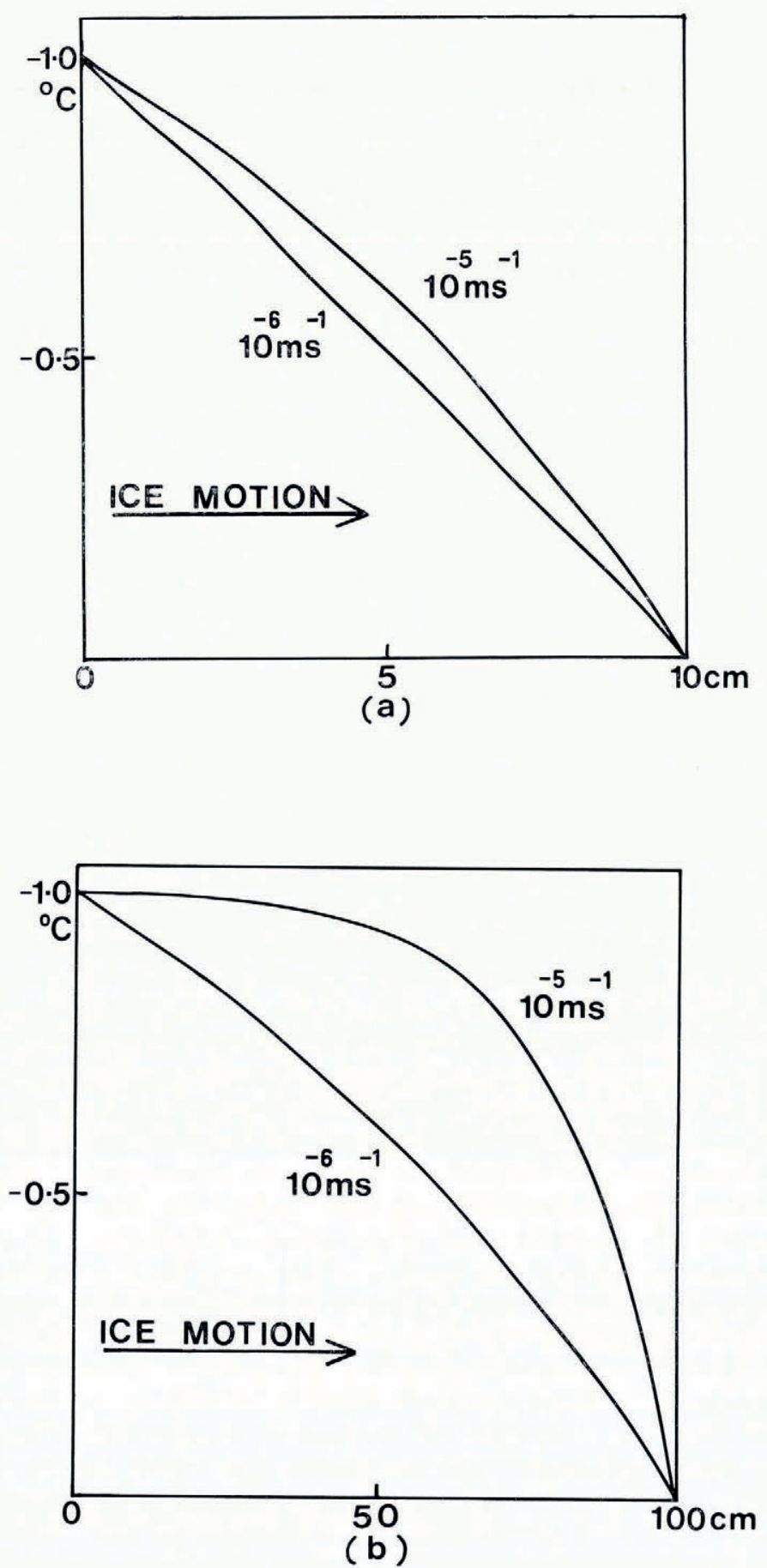

Fig. 2. Effect of linear motion of ice on temperature distribution between two stationary boundaries held at $-I^{\circ} \mathrm{C}$ and $o^{\circ} \mathrm{C}$. 
thick, but an average thickness judged to be about $5 \mathrm{~mm}$. This indicates general agreement of theory with observation. However, for his other case, with a sliding velocity of I $_{2} 8 \mathrm{~m} \mathrm{a}^{-1}$ he writes: "In field example 4, a regelation layer 8 to $\mathrm{I} 4 \mathrm{~mm}$ thick was observed at the ice sole, but the source of this layer was inaccessible". He suggests that little weight can be given to the predictions in this case - with which we would agree, but nevertheless it would seem that the observations themselves are most important. Discussing his table 2, he writes (p. 716): "In example 4, massive amounts of regelation on a scale of about $35 \mathrm{~cm}$ were taking place around a bedrock obstacle making contact with the sole over an area of about the same size, whereas around an obstacle penetrating the ice over an area about 2 meters in diameter, extreme plastic deformation took place on this scale, with local plastic crumpling at wavelengths down to about $25 \mathrm{~cm}$ ".

Although bedrock characteristics may have differed between Kamb's examples no. 3 and no. 4, both were beneath the Blue Glacier and they show a greater regelation layer thickness when the velocity of sliding is much faster. This is the opposite of his theoretical predictions which predict a layer thickness an order of magnitude less for the higher velocity of sliding. We can see from our Figure $2 b$ that the velocity of sliding is such that neglect of heat advection is not justified. An order-of-magnitude calculation indicates the possible role of advection if we assume that the p.m.p. is I deg lower up-stream of the obstacle and that this lowered pressure-melting point is effective throughout a layer of $\mathrm{I} \mathrm{m}$ in thickness. If, as suggested later, this heat is replaced primarily by thermal conduction from the lower surface of ice, the amount of heat required to warm the ice to p.m.p. is $50 \mathrm{cal} \mathrm{cm}^{-2}\left(2.1 \times \mathrm{IO}^{-2} \mathrm{~J} \mathrm{~m}^{-2}\right)$, which is sufficient to freeze a layer $6 \mathrm{~mm}$ thick to the base of the ice. We see later from Figure $4 \mathrm{~b}$ that the time taken for conduction of most of the heat from a layer $50 \mathrm{~cm}$ thick would be about $60 \mathrm{~h}$, during which time the ice would have moved $0.75 \mathrm{~m}$. We should need to increase the time and movement by a factor of four to allow for a layer $\mathrm{I} \mathrm{m}$ thick, but even so, it appears that advection of heat by moving ice, together with some contribution from thermal conduction, could explain the layer thicknesses observed on a semi-quantitative basis as well as showing why the regelation layer thickness can increase with sliding velocity. We discuss the effect of the $2 \mathrm{~m}$ obstacle later.

Another factor discussed in Lliboutry (1968) is the carriage of heat by the liquid moving from the up-stream to down-stream face, and he shows that it is small. He also considers the freezing of any liquid water content (within the ice) up-stream of an obstacle and its melting down-stream as a result of thermal conduction from the ice-rock boundary (Lliboutry, I964-65, Tom. 2, fig. i6.20.A). However, some new thinking appears necessary in regard to any free water in ice entering a pressure field due to a bedrock irregularity.

Harrison (1972) has discussed many aspects of the interaction between temperature, pressure, and impurity content of glacier ice close to p.m.p.. but he has not dealt with the effects of relatively rapid changes of pressure as ice moves past an irregularity in the bedrock. Consider the effect of taking a sample of ice at the pressure-melting point in a perfectly insulated box and applying additional hydrostatic pressure. The pressure-melting point will be lowered, and either the ice temperature must change to this new temperature or the ice will be superheated. However, if any free water is present, superheating will not be possible since the temperature at any ice--water interface will adjust to the new p.m.p. Heat will then flow from the interior of any ice crystals and from the interior of any water mass within the ice to the interfaces, which will occur mainly at grain boundaries, and cause melting. In other words, the temperature of the main mass of ice is lowered by absorbing the excess heat in melting the ice, absorption of latent heat being a relatively efficient process. Thus, for a large pressure increase of ${ }_{13} \mathrm{MPa}$ ( 130 bars), corresponding to a lowering of p.m.p. of $\mathrm{I}$ deg, if we assume usual values of specific heat of ice, we will require only $0.6 \%$ of the volume of ice to melt. The problem is more complex if shear stresses are present (see Nye and Mae, 1972) but this is unlikely to modify the general picture. 
When we apply the above considerations to basal ice in a glacier we reach the opposite conclusion from that shown by Lliboutry. Where the ice movement brings ice under increasing pressure with time, that is up-stream of any bedrock protuberance, we expect some additional melting to occur. Down-stream of the obstacle we expect freezing as the ambient pressure decreases for any parcel of ice.

A further effect is likely in that, up-stream of the obstacle, the water in any veins or tubes along triple junctions of crystals will probably be squeezed out of the ice and flow towards any subglacial water film at lower pressure. However, this process is not likely to be reversible, since the tubes will collapse under high pressure if water is squeezed out, as observed by Carol (1947). Unless there is still some free water in the ice that can release latent heat by freezing when pressure is released, the ice will remain at the temperature of the colder p.m.p. until the ice mass can warm up again by thermal conduction and heating due to internal friction. This would explain Carol's further observation of "rigid" ice in the lee of an obstacle.

The above process amounts to a simple heat pump: ice is cooled by excess pressure and the latent heat removed by squeezing out the resultant melt water. This is the inverse of the warming of firn layers by percolation of melt water. The effect will be associated just as much with large irregularities of the glacier bed as with small ones. It is the magnitude of the pressure change in the ice and not thermal conduction that will determine the amount of melting per unit volume. The volume of ice affected may be much greater than that involved in the simple pressure-melting/thermal-conduction regelation process. This in turn further emphasizes that the advection and conduction processes in moving ice may be more important than thermal conduction through bedrock.

An adequate theory to account quantitatively for the suggested "heat pump" effect would be more complex than the present already complicated regelation-deformation theories. In addition to covering the same phenomena it should also take account of changing flow properties of ice, in the presence of pressure-melting phenomena. Drainage of water could be dealt with in terms of the hydrology of the intergranular veins in a temperate glacier discussed in Shreve (1972) and Nye and Frank (1973). Figures in the latter paper for drainage under gravity suggest that water could be squeezed out very readily by pressure gradients of the magnitude that one would expect around bedrock irregularities. A full theory would also take into account changed flow properties in any zone cooled below the p.m.p.

In the absence of an adequate quantitative theory, we can turn to field observations to estimate the extent of any "heat pump" effect. I have already suggested (p. I 86) that appreciable internal melting takes place throughout the basal layer or "sole" of a glacier. The pumping process would also help to explain the relatively bubble-free nature of the sole, since air bubbles would tend to be expelled along with the water being squeezed out of the capillaries. Field observations indicate that the thickness of the "sole" of a glacier is usually about one metre, with variations from $30 \mathrm{~cm}$ to $2 \mathrm{~m}$ being common, and even greater thicknesses being possible. Our discussions of ice temperatures around subglacial cavities indicated that temperatures around I deg below p.m.p. were present. Thus we can suggest that the heat pump effect will suffice to chill a basal layer up to a metre or two in thickness by an amount of the order of I deg. We have used these rough figures already in estimating the amount of basal regelation ice that can be formed due to advection of heat, and found rough agreement with observations.

There seems no reason to doubt that these processes can take place under considerable thicknesses of ice, and that production of cold ice could eliminate a thin film of melt water that would otherwise be present. The processes discussed act in addition to the effects of heat conduction discussed by Lliboutry, and the heat pump effects are likely to be dominant, especially in regard to larger irregularities of the glacier bed.

We now consider the distance along a flow-line that may remain below p.m.p. downstream of an obstruction that produced ice at a temperature $\theta_{\mathrm{b}}$ below the p.m.p. $\left(\theta_{\mathrm{m}}\right)$. We 
take the mean basal shear stress over the cold area as $\bar{\tau}$, the velocity of movement as $v$ and the length across a given area as $D$. The movement may be considered as sliding at the base, or strong shear concentrated over a height less than $D$. The total frictional energy produced over distance $D$ will be $\bar{\tau} v D$. As long as this is less than the energy transported by heat flow, $K\left(\theta_{\mathrm{m}}-\theta_{\mathrm{b}}\right) H \mid D$, the basal ice will be below p.m.p. $H$ is the effective area (height by unit width) from which heat flows. The approximate width of the cold area $D_{\mathrm{c}}$ is then given by

$$
D_{\mathrm{c}}^{2}=\frac{K\left(\theta_{\mathrm{m}}-\theta_{\mathrm{b}}\right) H}{\bar{\tau} v},
$$

or if we consider $H \approx D_{\mathrm{c}}$, which is a rough approximation as long as the thickness of the cold layer is less than $D_{\mathrm{c}}$, we have

$$
D_{\mathrm{c}} \approx \frac{K\left(\theta_{\mathrm{m}}-\theta_{\mathrm{b}}\right)}{\bar{\tau} v}
$$

However, if the calculated $D_{\mathrm{c}}>H$, we put $D_{\mathrm{c}}=H=2.5 \mathrm{~m}$ in Table I below, since this is an approximate upper limit to the thickness of the sole of many glaciers.

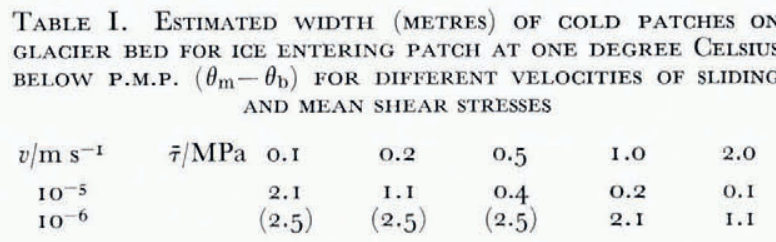

Table I should be taken as indicating only the order of magnitude of the size of cold patches for several reasons. Field evidence suggests that $\left(\theta_{\mathrm{m}}-\theta_{\mathrm{b}}\right)$ is often around I deg, but it should be larger for faster-moving glaciers. The figures do not take into account advection of heat by moving ice, hence values of $D_{\mathrm{c}}$ for a velocity of $\mathrm{IO}^{-5} \mathrm{~m} \mathrm{~s}^{-1}$ will be underestimates. Furthermore, the calculations are based on a two-dimensional model, but heat flow in the third dimension will increase the value of $D_{c}$, especially in the case of smaller values. From our earlier discussion of the friction of ice on cold surfaces, we expect that the appropriate value of $\bar{\tau}$ will be considerably above the mean basal shear stress, with 0.2 to $1.0 \mathrm{MPa}$ ( 2 to Io bars) as a likely range. These are not the same as the high stress concentrations producing the cold ice up-stream of the cold patch.

Our general conclusion from Table I is that cold patches are likely to range in size from tens of centimetres to a couple of metres across, which agrees with suggestions based on earlier field evidence. It is also consistent with further evidence described in Kamb (1970) for his example (4) already mentioned on p. I89. He describes strong deformation but makes no mention of any regelation ice down-stream of a $2 \mathrm{~m}$ obstacle, whereas massive amounts of regelation were present with an obstacle of $35 \mathrm{~cm}$. The ice movement of $128 \mathrm{~m} \mathrm{a}^{-1}$ means that regelation would be due primarily to advection of heat, especially for the larger obstacle, but we would expect regelation to cease once the ice has been reheated over the distances $D_{\mathrm{c}}$. Thus observations by Kamb appear consistent with Table I.

\section{Cold PATChes due to Thermal Gonduction}

In addition to cold basal areas caused by streaming of colder ice, we must also consider whether cold patches could result from thermal conduction through bedrock around areas of stress concentration. Such areas need not be oriented in the flow direction. An example of this effect is shown in Figure 3, redrawn from a photograph shown as figure 3 of Kamb and LaChapelle ( 1964$)$. The cross-section in this case is taken along a flow-line. 


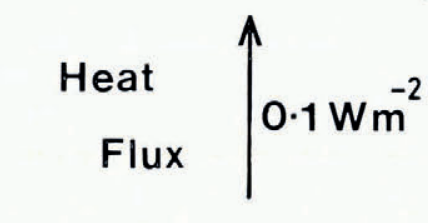

$\stackrel{\text { ICE MOVEMENT }}{\longleftarrow}$

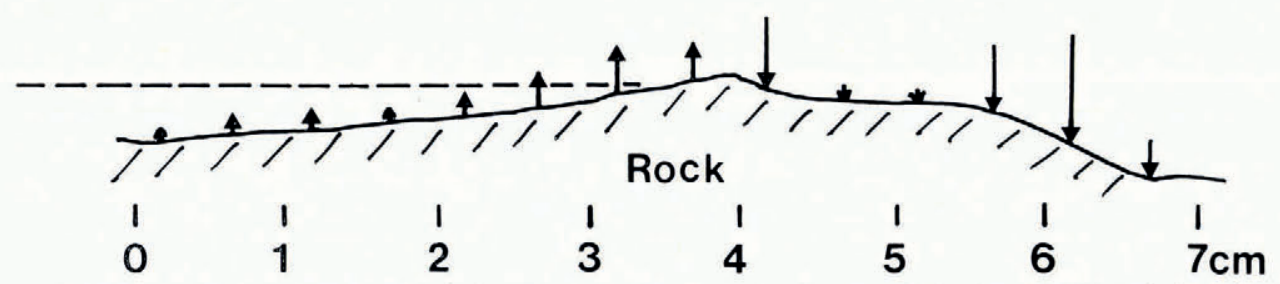

Fig. 3. Heat flux at ice-rock boundary for profile along flow-line shown in figure 3 of Kamb and LaChapelle (1964). This assumes that ice motion throughout is parallel to the dashed line indicating the approximate upper limit of regelation ice, so that heat fluxs corresponding to pressure melting on the up-stream face and regelation down-stream of the high point of rock can be calculated from the angle between the ice motion and rock surface at any point. Numerical values of flux are proportional to length of the arrow, the scale being given by the sample arrow for heat flux $0.1 \mathrm{~W} \mathrm{~m}^{-2}$. A heat flux towards the ice-rock interface indicates melting and vice versa.

We have calculated the heat fluxes on the assumption that basal melting or freezing is proportional to $v \sin \theta$ at any point, $\theta$ being the angle between the direction of ice motion and the slope of bedrock. The direction of ice motion is regarded as constant throughout the zone considered, as Kamb and LaChapelle observed no shear and the upper boundary or regelation ice (dashed line) on the left is straight. The sign convention for $\theta$ in terms of melting (inflow of heat) or freezing is obvious. We see that up-stream (right) of the rock crest, we have two outer zones where the heat flux associated with pressure melting should be substantially greater than in the area between. In these circumstances, it is difficult to see how the central section could be warmed by circulating melt water. It seems more likely that the central section will remain frozen due to conduction from adjacent colder patches, although these patches are at p.m.p. The scale of these features is such that thermal conduction rather than advection of heat will govern the basal temperatures. This case provides a field example of the problems discussed in Nye (1973) in relation to some paradoxes met in regelation theory, although he approaches the problem from a theoretical and laboratory point of view.

\section{TIME VARIATION OF BASAL WATER PRESSURE}

It has been well established by Mathews (1964), and others, that the hydrostatic pressure in the basal film of water can vary considerably and rapidly as the result of variations of water supply to the bed of the glacier. Field observations (Theakstone, 1967) have shown that there is a close relationship between basal water supply and the velocity of sliding. General theories describing water at the base of a glacier by Lliboutry (1964-65, Ch. I6), Weertman (1972), and others, indicate that over much of the basal area, the pressure in the water layer is lower than the ice overburden pressure. However, the total weight of ice over a large area must be in balance with the mean vertical load on bedrock. According to Weertman (1972) the thickness of the water sheets is not uniform, but squeezes to negligible values at high pressure zones where the ice moves over irregularities in the bed. According to this paper, highpressure loading of the bed will take place both on cold patches of area $A_{\mathrm{C}}$ and on zones with high-pressure water films of area $A_{\mathrm{H}}$. Then if considerable changes in basal water pressures take place under the major area $A_{\mathrm{L}}$ of a glacier where a low-pressure water film is present, the proportion of the load supported by high-pressure zones and cold patches will change. 
We have little information on which to estimate the ratio of the areas $A_{\mathrm{L}} /\left(A_{\mathrm{C}}+A_{\mathrm{H}}\right)$. Weertman (1957) with a similar problem took a ratio of obstacle area to low-friction area of I $6:$ I. When many holes have been drilled to the base of temperate glaciers, as reported in Hodge (1976), one may get a statistical idea of the ratio. When such a hole reaches an area where the basal water film is at low pressure, the water level drops rapidly (p. 207). However, if the hole reaches bedrock at an area that is either frozen $\left(A_{\mathrm{C}}\right)$ or at high pressure $\left(A_{\mathrm{H}}\right)$, the water level will not change appreciably in the hole either because of lack of basal water, or because the volume supply of water from a high-pressure film only micrometres thick will not be sufficient to cause an appreciable rise of water level, although it will prevent a drop until the ice slides clear of the high-pressure area. In the absence of enough data, we suggest that the order of magnitude of the low to high pressure areas, $A_{\mathrm{L}} /\left(A_{\mathrm{C}}+A_{\mathrm{H}}\right) \approx \mathrm{IO} / \mathrm{I}$. In this case a rise in the general basal pressure of, say, I.3 $\mathrm{MPa}$ ( $\mathrm{I}_{3}$ bar) will cause a fall in basal pressure over areas $\left(A_{\mathrm{C}}+A_{\mathrm{H}}\right)$ of $\mathrm{I}_{3} \mathrm{MPa}$ (I 30 bar) which can then increase in temperature by I deg to attain equilibrium with the new basal pressures. However, this will take time, which will depend on the areas and volumes of ice and rock at low temperatures that must be warmed up by conduction and internal friction. The initial effect, if basal water pressures rise rapidly, will be to freeze any water film at the ice-rock contact over areas $A_{\mathrm{H}}$, and increase friction over any areas $A_{\mathrm{C}}$ as the difference between the pressure-melting point and actual temperatures increases. Kamb and LaChapelle have shown that this basal freezing takes place when mean loads fall by relatively small amounts during excavation of tunnels, so, with a mechanism that can change pressures by I $_{3} \mathrm{MPa}$ ( 130 bar), there is little doubt that this mechanism must be of importance. The first effect of such freezing of ice to bedrock over high-pressure and cold zones will be to slow down or stop the sliding of ice over such areas. However, any such stoppage over local areas will come under additional stress due to movement of surrounding ice over areas underlain by a water film. Internal stresses around cold areas will then build up, apparently until they are high enough to induce melting under stress or until fracture of ice near the bedrock relieves the stress. The above processes present a likely explanation for intermittent movement of temperate glaciers due to large-scale stick-slip effects resulting from variations of basal water pressures and ice temperatures with time. Some idea of the time scale for the relevant heat conduction processes can be gained from the time necessary to warm up slabs of thicknesses of o. $1 \mathrm{~m}$ and $1.0 \mathrm{~m}$ (Carslaw and Jaeger,

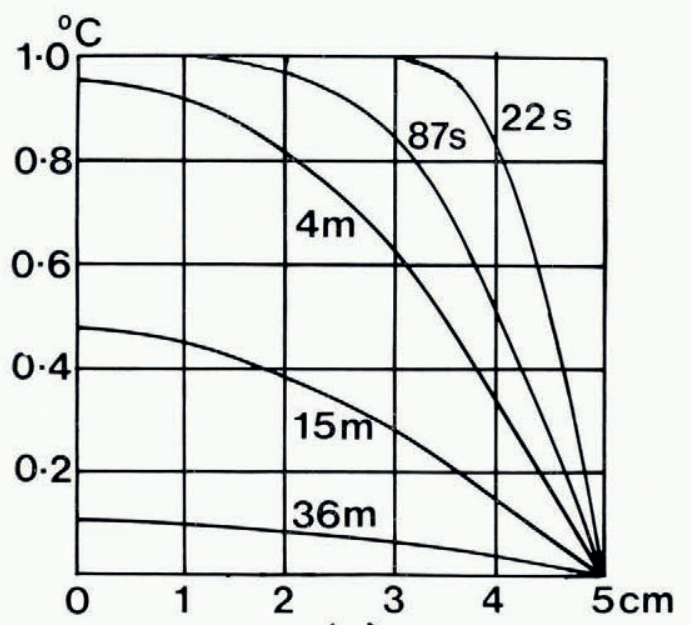

(a)

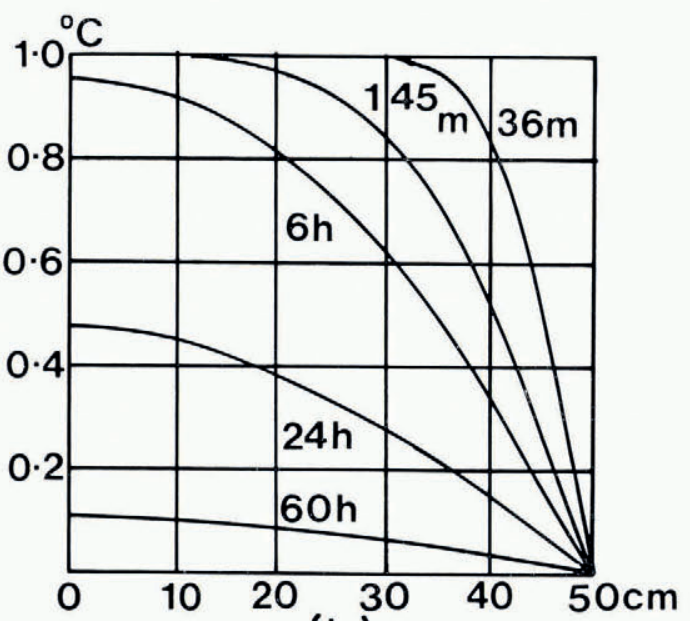

(b)

Fig. 4. Temperature distribution in a slab of ice of half width $(a) 5 \mathrm{~cm}$, and $(b) 50 \mathrm{~cm}$, at various times after the boundary temperature has been changed from $-I$ to $0^{\circ} \mathrm{C}$. There is no heat flux at zero distance, the centre of the slab. 
I 959 , p. 98). In this case we must think of the slab as a vertical section through ice and rock. We see that for a $10 \mathrm{~cm}$ thickness (half slab $5 \mathrm{~cm}$ ), approximately half the heat necessary for warming penetrates the slab in about $6 \mathrm{~min}$, whereas for $0.5 \mathrm{~m}$ thickness this will take about $3 \mathrm{~h}$, and for $\mathrm{I} . \mathrm{O} \mathrm{m}$ about $\mathrm{I} 2 \mathrm{~h}$. However, in $3 \mathrm{~h}$, ice surrounding a cold stationary patch will have moved forward by $12 \mathrm{~cm}$ beneath the Glacier d'Argentière, or by I $\mathrm{cm}$ beneath Østerdalsisen. It appears likely that stress effects and internal friction will be more effective at warming larger areas under faster-moving glaciers than will thermal conduction. We can conclude from Figure 4, however, that sticking areas must be of a minimum width of at least o. I $\mathrm{m}$, but may be considerably larger.

One prediction that follows from the above model is that irregular stick-slip motion of a glacier is most likely to occur at times when subglacial water pressures are rising most rapidly. The reverse effect due to rapid falls of general basal water pressure are unlikely to cause much stick-slip motion due to increased basal melting over high pressure zones, although friction over cold areas should decrease. During winter months when basal water pressures are likely to remain steady, we would expect a relative absence of stick-slip phenomena and a steady rate of sliding.

\section{ERosion}

In addition to showing how rapidly the friction between ice and a flat surface of granite rises with fall of temperature below the p.m.p., Barnes and others (197I) have shown by indentation tests that the hardness of ice can change by a factor of two or three for a temperature change of a few tenths of a degree through the pressure-melting point. The main consequence of the present paper is to show that we may expect maximum erosion by grinding to take place on our cold patches - which we see will tend to be on the flatter tops of features such as roches moutonnées, rather than on the up-stream faces where pressure-melting takes place. The latter areas may however be eroded during intermittent freezing caused by changes of basal water pressure. Another consequence of intermittent basal freezing in some areas could be considerable changes in basal shear stresses. Suggested magnitudes of such changes could possibly be around I.O MPa (Io bars), and over areas of say $\mathrm{IO}^{3} \mathrm{~cm}^{2}$ this would imply a "plucking" force that could vary quite rapidly by some $\mathrm{IO}^{5} \mathrm{~N}$ (Io tons weight) over an area of $32 \mathrm{~cm} \times 3^{2} \mathrm{~cm}$.

Thus, several well established features of erosion by temperate glaciers are explained when changes of pressure in the ice mass with time and with position are interpreted in terms of changes of the pressure-melting point within the ice.

\section{Conclusion}

The question in the title of this paper has been answered at some length due to the complex interactions between pressure, temperature, and motion of ice in a temperate glacier. Although the major part of a temperate glacier must be underlain by a film of water, a strong case has been made for the existence of patches of the order of 0 . I to I $\mathrm{m}$ in extent, over which temperatures may be below the pressure-melting point. Intermittent occurrence of such patches of the same, or larger, area must also take place under glaciers where the pressure in the main volume of the basal water layer varies rapidly with time.

\section{REFERENCES}

Ahlmann, H. W. 1935. Contribution to the physics of glaciers. Geographical fournal, Vol. 86, No. 2, p. $97-113$. Barnes, P., and Robin, G. de Q. 1966. Implications for glaciology. Nature, Vol. 210, No. 5039, p. 882-83.

Barnes, P., and Tabor, D. 1966. Plastic flow and pressure melting in the deformation of ice I. Nature, Vol. 2 Io, No. 5039, p. 878-82. 
Barnes, P., and Tabor, D. 1968. Plastic flow and pressure melting in the deformation of ice I. Union de Géodésie et Géophysique Internationale. Association Internationale d'Hydrologie Scientifique. Assemblée générale de Berne, 25 sept.7 oct. 1967. [Commission de Neiges et Glaces.] Rapports et discussions, p. 303-15.

Barnes, P., and others. I97I. Friction and creep of polycrystalline ice, by P. Barnes, D. Tabor and J. C. F. Walker. Proceedings of the Royal Society of London, Ser. A, Vol. 324, No. 1557, p. 127-55.

Carol, H. 1947. The formation of roches moutonnées. Fournal of Glaciology, Vol. I, No. 2, p. 57-59.

Carslaw, H. S., and Jaeger, J. C. r959. Conduction of heat in solids. Second edition. Oxford, Clarendon Press.

Harrison, W. D. 1972. Temperature of a temperate glacier. Fournal of Glaciology, Vol. i i, No. 61, p. i 5-29.

Hodge, S. M. 1976. Direct measurement of basal water pressures: a pilot study. Fournal of Glaciology, Vol. 16, No. 74, p. $205^{-1} 8$.

Kamb, W. B. 1970. Sliding motion of glaciers: theory and observation. Reviews of Geophysics and Space Physics, Vol. 8, No. 4, p. 673-728.

Kamb, W. B., and LaChapelle, E. R. 1964. Direct observation of the mechanism of glacier sliding over bedrock. Fournal of Glaciology, Vol. 5, No. 38, p. I 59-72.

Lliboutry, L. A. 1962 . L'érosion glaciaire. Union Géodésique et Géophysique Internationale. Association Internationale d'Hydrologie Scientifique. Commission de l'Érosion Continentale. Colloque de Bari, $1-10-8-10,1962$, p. $219-25$.

Lliboutry, L. A. 1964-65. Traité de glaciologie. Paris, Masson et Cie. 2 vols.

Lliboutry, L. A. 1968. General theory of subglacial cavitation and sliding of temperate glaciers. Fournal of Glaciology, Vol. 7, No. 49, p. 2 I-58.

Mathews, W. H. I964. Water pressure under a glacier. Journal of Glaciology, Vol. 5, No. 38, p. 235-40.

Nye, J. F. 1969. A calculation of the sliding of ice over a wavy surface using a Newtonian viscous approximation. Proceedings of the Royal Society of London, Ser. A, Vol. 311 , No. 1506 , p. 445-67.

Nye, J. F. 1973. The motion of ice past obstacles. (In Whalley, E., and others. ed. Physics and chemistry of ice: papers presented at the Symposium on the Physics and Chemistry of Ice, held in Ottawa, Canada, I4-18 August 1972. Edited by E. Whalley, S. F. Fones, L. W. Gold. Ottawa, Royal Society of Canada, p. 387-94.)

Nye, J. F., and Frank, F. C. 1973. Hydrology of the intergranular veins in a temperate glacier. Union Géodésique et Géophysique Internationale. Association Internationale d'Hydrologie Scientifique. Commission de Neiges et Glaces. Symposium on the Hydrology of Glaciers, Cambridge, 7-13 September 1969, p. 157-61 .

Nye, J. F., and Mae, S. r 972 . The effect of non-hydrostatic stress on intergranular water veins and lenses in ice. Journal of Glaciology, Vol. i 1, No. 61, p. 81-ior.

Raraty, L. E., and Tabor, D. I958. The adhesion and strength properties of ice. Proceedings of the Royal Society of London, Ser. A, Vol. 245, No. 124I, p. 184-201.

Shreve, R. L. I972. Movement of water in glaciers. Journal of Glaciology, Vol. I I, No. 62, p. 205-14.

Theakstone, W. H. I967. Basal sliding and movement near the margin of the glacier Østerdalsisen, Norway. Journal of Glaciology, Vol. 6, No. 48, p. 805-16.

Vivian, R., and Bocquet, G. 1973. Subglacial cavitation phenomena under the Glacier d'Argentière, Mont Blanc, France. Fournal of Glaciology, Vol. 12, No. 66, p. 439-51.

Weertman, J. 1957. On the sliding of glaciers. Fournal of Glaciology, Vol. 3, No. 2 I, p. 33-38.

Weertman, J. ig64. The theory of glacier sliding. Fournal of Glaciology, Vol. 5, No. 39, p. $287-303$.

Weertman, J. 1972. General theory of water flow at the base of a glacier or ice sheet. Reviews of Geophysics and Space Physics, Vol. 10, No. 1, p. 287-333.

\section{DISCUSSION}

W. D. Harrison: I believe you stated that part of the reason for heat pumping was that water once squeezed out could not be introduced again because of collapse of veins or other channels. It does not seem necessary to reintroduce the water to keep the ice warm. If the water refreezes on the down-stream side of the pump, in the conventional fashion, conduction of heat from that source can perhaps replace the water in the ice.

G. DE Q. Robin: Certainly this will occur. However, the heat pump mechanism could take place through the entire ice mass affected by the local pressure disturbances. The volume so arfected is likely to be much more than the volume affected by thermal conduction in the ice niass. For small-scale effects, millimetres or centimetres in size, thermal conductivities may be more important, but for decimetres and up to a metre or more, the heat pump action is likely to be much more effective in cooling the ice, than is conductivity in rewarming it.

L. Lliboutry: When there is no rock-ice separation (only a water film $\mathrm{I} \mu \mathrm{m}$ thick), the convection of cold by moving ice has been shown by Nye to be negligible. Your effect should exist for high sliding velocities, when large cavities (no longer "films") appear at the lee of the obstacles. In this case most of the cold ice is at the roof of the cavity, not in contact with the bedrock. 
I have given another plausible explanation of a stick-slip movement. When there is no sliding, obstacles enter into the ice. The friction must then increase very much in order that cavities can form. When cavities are formed, the friction drops.

RoBIN: I would not agree with your interpretation of Nye's calculations. In the first place, separation takes place only in the lee of obstacles, whereas my remarks apply to heat transport at all points. Such points include the top of obstacles where bottom slopes may still prevent separation.

Certainly the effects of cavitation must be considered. I agree that they provide another possible explanation of stick-slip motion. We now need observations to see if either of the two mechanisms provides a satisfactory explanation.

W. F. Budd: As a general comment we have now commenced sliding experiments which indicate the Barnes and others (I97I) curves to be strongly dependent on the surface roughness. As a result, for rougher ice, it may not be necessary to have the temperature as low as $-0.5^{\circ} \mathrm{C}$ to have drops in effective coefficients of friction at the appropriate velocity. Also, other parameters which seem to be important include: the debris in the ice, the washing away of the debris by the melt water and the cooling of the ice by the escape of the melt water instead of refreezing.

Robin: I welcome these studies as we need much more information on these processes. 